\title{
EFFECT OF ACCELERATED WEATHERING AND LEACHING ON THE CHEMISTRY AND PHYTOTOXICITY OF COAL-MINE OVERBURDEN
}

\author{
JAN FROUZ1,2,*, RADKA ZADINOVÁ², MARTIN MIHALJEVIČ³, \\ PETR ROJÍK ${ }^{4}$, and MICHAL ŘEHOR ${ }^{5}$ \\ ${ }^{1}$ Institute of Soil Biology, Biology Centre, v.v.i., Na Sádkách 7, 37005 České Budějovice, Czech Republic \\ ${ }^{2}$ Institute for Environmental Studies, Faculty of Science, Charles University in Prague, Benátská 2, 12843 Prague, Czech Republic \\ ${ }^{3}$ Institute of Geochemistry, Mineralogy and Mineral Resources, Faculty of Science, Charles University in Prague, Albertov 6, 128 43 \\ Prague, Czech Republic \\ ${ }^{4}$ Př́bramská 381, Rotava, Czech Republic \\ ${ }^{5}$ Institute for Brown Coal, Budovatelů 2830, 43437 Most, Czech Republic \\ * Corresponding author: frouz@natur.cuni.cz
}

\begin{abstract}
Overburden weathering may influence its effects on soil development and plant growth. Here, an accelerated-weathering experiment was used to determine how weathering affects the chemistry and toxicity of coal-mine overburden. Seven samples of overburden were collected; two samples were from a heap of partly weathered material, and five from mining pits. In both cases, the most weathered top $10 \mathrm{~cm}$ was removed. Samples included coal-rich clays (with $>1 \%$ coal) and coal-free clays. The samples were artificially weathered by subjecting them to 20 cycles of drying-rewetting-freezing-thawing. Coal-rich clays that have not been weathered were acidic and toxic to Sinapis alba seedlings, but weathering increased their $\mathrm{pH}$, reduced their conductivity and tended to reduce their phytotoxicity. In contrast, weathering tended to reduce the $\mathrm{pH}$ of coal-free alkaline clays. S. alba grew poorly in weathered coal-free clay, but when grown in coal-rich clays it grew better in some substrates whereas others were phytotoxic due to their high As content. Weathering decreased $\mathrm{Al}, \mathrm{As}$ and $\mathrm{Na}$ contents and decreased substrate mass by $1-37 \%$. Overall, these results indicate that weathering changes the properties of overburden in ways that are important for soil development and plant growth but the nature and extent of the changes depend on the initial composition of the substrate.
\end{abstract}

Keywords: mining, reclamation, coal, toxicity, plant

\section{Introduction}

Mining provides essential resources for society but has devastating effects on the environment. This is particularly true of open-cast coal mining, during which original ecosystems are either mined out or covered by overburden. Overburden differs substantially from soil in terms of its texture, $\mathrm{pH}$, salinity and toxic metal content (Bradshaw 1997). Many of these adverse properties of overburden are associated with weathering; weathering of pyrite, for example, results in acidification (Bradshaw 1997; Silva et al. 2011).

In spite of these problems, overburden is often used in reclamation, i.e., it is re-vegetated in situ or used as a substitute for topsoil (Helingerová et al. 2010; Zipper et al. 2011). Although the toxicity and plant performance in fresh overburden has been studied (Frouz et al. 2004; Frouz et al. 2011b), little is known about how the growth of plants in overburden changes as the overburden weathers. Changes in the properties of overburden during weathering have been studied by means of subjecting overburden to artificial weathering (Haering et al. 1993; Doolittle and Hossner 1997; Silva et al. 2011). In this study, we compared plant growth in artificially-weathered and un-weathered overburden that differed in composition (coal-rich vs. coal-free) and history. We also measured the effects of weathering on selected chemical and physical properties of different kinds of overburden.

\section{Material and Methods}

\section{Sampling Site}

Samples were collected in the Sokolov coal mining district in western Bohemia. The material sampled consisted of Miocene clay sediment that was deposited in meromictic lakes 21.3-16.5 Ma BP (Rojík 2004). In general, the clay sediments in the Sokolov Basin are a mixture of kaolinite, illite and montmorillonite, with kaolinite dominant in deeper layers near the coal seam (Kř́bek et al. 1998; Rojík 2004). Seven samples were collected in October 2009. Two samples (CCW and CW in Table 1) were of partially weathered material that was removed from its original location in mining pits and deposited in a heap at least 20 years prior to this study. The other five samples were collected directly from mining pits. In all cases, the most-weathered top $10 \mathrm{~cm}$ was removed, and about $3 \mathrm{~kg}$ of overburden collected from a $50 \times 50 \mathrm{~cm}$ area. The samples consisted of coal-rich clay (containing more than $1 \%$ of coal; samples CCW, CC1, CC2, CC3) and coal-free clay (samples C1, C2, and CW). Sampling locations and mineral compositions of the samples are presented in Table 1. In general, coal-rich samples had a higher proportion of silt, sand and fine gravel than coal-free samples, while coal-free samples consisted of compacted clay mudstones.

Because of the disturbance caused by sampling and natural cracks in the overburden, all the material sam- 
Table 1 Location of the sites sampled and composition of the samples of sediments used in the weathering experiment. Composition was determined using X-ray diffraction and microscopic observation. $\mathrm{CC}=$ coal-rich clay, $\mathrm{C}=\mathrm{clay}, \mathrm{W}=$ material that was mined and deposited in a heap and weathered for at least 20 years before sampling.

\begin{tabular}{|c|c|c|c|c|}
\hline Sample name & Sample Location & Coordinates & Minerals with $>10 \%$ content & Minerals with $1-10 \%$ content \\
\hline $\mathrm{CCW}$ & Spoil heap & $\begin{array}{l}50^{\circ} 12^{\prime} 45.699^{\prime \prime} \mathrm{N} \\
12^{\circ} 38^{\prime} 42.892^{\prime \prime} \mathrm{E}\end{array}$ & kaolinite, quartz, muscovite, coal & anatas \\
\hline $\mathrm{CC} 1$ & Mine pit & $\begin{array}{c}50^{\circ} 11^{\prime} 38.82^{\prime} \mathrm{N} \\
12^{\circ} 39^{\prime} 56.198^{\prime \prime} \mathrm{E}\end{array}$ & kaolinite, quartz & muscovite, coal \\
\hline $\mathrm{CC} 2$ & Mine pit & $\begin{array}{l}50^{\circ} 14^{\prime} 24.831^{\prime \prime} \mathrm{N} \\
12^{\circ} 43^{\prime} 26.011^{\prime \prime} \mathrm{E}\end{array}$ & kaolinite, quartz & illite, sericite, muscovite, coal \\
\hline $\mathrm{C} 1$ & Mine pit & $\begin{array}{l}50^{\circ} 11^{\prime} 32.104^{\prime \prime} \mathrm{N} \\
12^{\circ} 40^{\prime} 10.044^{\prime \prime} \mathrm{E}\end{array}$ & kaolinite & siderite, quartz, muscovite \\
\hline C3 & Mine pit & $\begin{array}{l}50^{\circ} 11^{\prime} 35.173^{\prime \prime} \mathrm{N} \\
12^{\circ} 40^{\prime} 14.535^{\prime \prime} \mathrm{E}\end{array}$ & kaolinite, quartz & muscovite, siderite, illite, algal kerogen \\
\hline C3 & Mine pit & $\begin{array}{l}50^{\circ} 11^{\prime} 37.092^{\prime \prime} \mathrm{N} \\
12^{\circ} 40^{\prime} 16.561^{\prime \prime} \mathrm{E}\end{array}$ & kaolinite quartz & muscovite, illite \\
\hline $\mathrm{CW}$ & Spoil heap & $\begin{array}{l}50^{\circ} 15^{\prime} 16.897^{\prime \prime} \mathrm{N} \\
12^{\circ} 44^{\prime} 12.218^{\prime \prime} \mathrm{E}\end{array}$ & kaolinite, quartz, illite & muscovite, calcite, siderite, algal kerogen \\
\hline
\end{tabular}

pled broke into small fragments $(<3 \mathrm{~cm}$ in diameter $)$ after sampling.

In the laboratory, four $200 \mathrm{~g}$ subsamples of each sample were prepared. a $100 \mathrm{~g}$ quantity of each subsample was placed in a $250 \mathrm{ml}$ plastic bottle without additional crushing. The remaining $100 \mathrm{~g}$ of each subsample was dried at $<40{ }^{\circ} \mathrm{C}$ for 2 days; this "unweathered" part was used to determine the initial dry mass and then stored for chemical analyses.

The material in the bottles was subjected to artificial weathering and leaching. After $50 \mathrm{ml}$ of distilled water was added to each bottle, the bottles were shaken by hand, left undisturbed overnight to allow the material to absorb the water, and then placed in a $-18{ }^{\circ} \mathrm{C}$ freezer. After $24 \mathrm{~h}$, the bottles were removed from the freezer, and the material was allowed to thaw at $22^{\circ} \mathrm{C}$ for 1 day. After the material had thawed for 1 day, the excess water was decanted and the samples were dried for 2 days at $40^{\circ} \mathrm{C}$. After the 2 days of drying, $50 \mathrm{ml}$ of water was added to each bottle and the entire process repeated. In total, each bottle was subjected to 20 cycles of wetting, freezing, thawing, decanting and drying. The water that was decanted after the first and last cycle was used to measure $\mathrm{pH}$ and conductivity. During the first and last cycle, the sample was weighed after decanting the water to determine the water-holding capacity of the substrate. This was calculated as the weight of water stored in the sample during the first or last cycle as a percentage of the dry weight of soil before or after weathering, respectively.

The remaining "weathered" material was dried and weighed to determine mass loss and was also used for chemical analyses and used in a plant bioassay. Here, the term "weathered" is used to describe the material after weathering and leaching; dissolved and suspended matter removed by percolating water is not included, even if it is a product of weathering. This is because we aimed to mimic changes that occur in the surface layer of overbur- den as a consequence of weathering and leaching, rather than whether weathering affects the growth of plants.

For the chemical analyses of unweathered and weathered samples, available $\mathrm{Ca}, \mathrm{Na}$ and $\mathrm{Al}$ in each subsample was extracted by placing $5 \mathrm{~g}$ of material in $20 \mathrm{ml}$ of Mehlich I solution (Mehlich 1953). For determination of the As content, $1 \mathrm{~g}$ of each subsample was finely ground and mineralized in nitrohydrochloric acid. The $\mathrm{Ca}, \mathrm{Na}$ and $\mathrm{Al}$ in the extracts and the As in the mineralized subsample were quantified using a SpectrAA 640 atomic absorption spectrophotometer (Varian, Inc. USA) at $420.7 \mathrm{~nm}$. Organic matter content of samples was determined by loss on ignition (LOI) of a $2 \mathrm{~g}$ quantity after $5 \mathrm{~h}$ at $600{ }^{\circ} \mathrm{C}$.

For the plant bioassay, seed was germinated and the growth of Sinapis alba plants growing in unweathered and weathered overburden was measured as described previously (Frouz et al. 2011b). Briefly, pots were filled with $50 \mathrm{~g}$ of substrate (four pots per substrate type) and 20 seeds of $S$. alba added to each pot. At the end of the bioassay, shoot lengths were measured (or recorded as 0 if the plants did not germinate).

Particle-size distribution was determined using the Casagrande method (Klute 1986) for unweathered and weathered material that was pooled from the four replicates of each treatment. Because most samples contained few or no clay-sized particles, the fraction of particles $<0.01 \mathrm{~mm}$ was used as a measure of sample disintegration.

For determination of mineralogical composition, a $5 \mathrm{~g}$ quantity of the unweathered material was finely ground and subjected to X-ray powder diffraction using a D 5000 Siemens diffractometer. Diffractograms in the

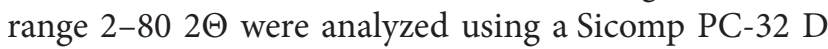
and Diffrac AT software. At the same time, unground unweathered samples were macroscopically and microscopically evaluated to obtain additional information on their composition. 
The data for unweathered vs. weathered samples were compared using $t$ tests. Correlation analysis was used to explore the relationships between some of the parameters (Pearson's $r$; computed using Statistica 10.0). Principal component analysis (PCA) was used to visualize changes in individual parameters in various types of substrates (computed using CANOCO 4.0.).

\section{Results}

The variability in the properties of unweathered substrates was substantial (Fig. 1; Tables 2, 3). The pH of these substrates was positively correlated with available Ca content $(r=0.766, p<0.05)$ and available $\mathrm{Al}$ content positively with $\mathrm{Na}$ content $(r=0.900, p<0.05)$. S. alba seedlings were unable to grow in two of the unweathered substrates (CCW and CC1) (Fig. 1D), which had low $\mathrm{pH}$ values (Fig. 1A), high conductivity values (Fig. 1C) and high As contents (Fig. 1B). The best predictor of plant growth in unweathered substrates was $\mathrm{pH}(r=0.950$, $p<0.05)$ and available $\mathrm{Ca}(r=0.916, p<0.05)$, with plant growth negatively correlated with As content or conductivity, but not significantly so.
Weathering resulted in a significant but highly variable reduction in the mass of all but two substrates $(\mathrm{Ta}-$ ble 2). Weathering increased the percentage of fine particles $(<0.01 \mathrm{~mm})$ in all but one substrate (Table 2$)$. The percentage of fine particles was not correlated with any other substrate property. Mass loss was correlated with water-holding capacity at the end of the experiment $(r=0.750, p<0.05)$. Weathering significantly increased water-holding capacity and significantly reduced organic matter content (LOI) of all substrates (Table 2).

Depending on the substrate, weathering either resulted in a decrease or did not affect available $\mathrm{Al}$ and $\mathrm{Na}$ (Table 3). Weathering resulted in a decrease in available $\mathrm{Fe}$ in one substrate (C1, a coal-free substrate) but not significantly that in other substrates (Table 3). Decrease during weathering of the contents of $\mathrm{Al}, \mathrm{Na}, \mathrm{Fe}$ and $\mathrm{As}$ was positively correlated with their contents in unweathered substrates ( $r=0.749,0.848,0.770$, and 0.972 for $\mathrm{Al}, \mathrm{Na}$, $\mathrm{Fe}$, and As, respectively; $p<0.05$ in each case).

Weathering resulted in significant changes in the $\mathrm{pH}$ of all substrates, with it increasing in acidic substrates and decreasing in alkaline substrates (Fig. 1A); the increase in $\mathrm{pH}$ caused by weathering was negatively correlated with the $\mathrm{pH}$ before weathering $(r=-0.967, p<0.05)$.

Table 2 Differences in mass (expressed in terms of loss of mass), organic matter content (loss on ignition, LOI), water-holding capacity and percentage of particles $<0.01 \mathrm{~mm}$ recorded in substrates before and after artificial weathering. Values are means \pm SD (but variance was not determined for particle size) and percentages are expressed on a weight-to-weight basis. An asterisk for LOI, water holding capacity and particle size indicates a significant difference between the means for weathered and unweathered substrates. Loss of mass was calculated as 1 - (mass of weathered substrate/mass of unweathered substrate) $\times 100$; an asterisk against loss of mass indicates that the mass of the weathered material was significantly lower than that of the unweathered material.

\begin{tabular}{|c|c|c|c|c|c|c|c|c|c|c|c|c|c|}
\hline \multicolumn{2}{|c|}{} & \multicolumn{4}{|c|}{ LOI (\%) } & \multicolumn{5}{c|}{ Water holding capacity (\%) } \\
$<0.01 \mathrm{~mm}(\%)$
\end{tabular}

Table 3 Content of available Fe, Al, Ca, and Na recorded before and after weathering. Values after \pm are SDs, $<2$ indicates that all samples were below detection limit, and * indicates a significant difference between values recorded before and after weathering.

\begin{tabular}{|c|c|c|c|c|c|c|c|c|c|c|c|c|c|c|c|c|}
\hline \multirow[b]{3}{*}{ CCW } & \multicolumn{4}{|c|}{ Fe $\mathrm{mg} \mathrm{kg}^{-1}$} & \multicolumn{4}{|c|}{ Al mg kg-1 } & \multicolumn{4}{|c|}{ Ca mg kg-1 } & \multicolumn{4}{|c|}{$\mathrm{Na} \mathrm{mg} \mathrm{kg-1}$} \\
\hline & \multicolumn{2}{|c|}{ before } & \multicolumn{2}{|c|}{ after } & \multicolumn{2}{|c|}{ before } & \multicolumn{2}{|c|}{ after } & \multicolumn{2}{|c|}{ before } & \multicolumn{2}{|c|}{ after } & \multicolumn{2}{|c|}{ before } & \multicolumn{2}{|c|}{ after } \\
\hline & 167.7 & \pm 0.0 & 197.7 & \pm 24.2 & 71.8 & \pm 4.1 & 74.1 & \pm 3.7 & 335 & \pm 90 & 316 & \pm 80 & 6.9 & \pm 1.1 & 6.2 & \pm 1.3 \\
\hline $\mathrm{CC} 1$ & 35.7 & \pm 1.1 & 40.0 & \pm 10.5 & 11.3 & \pm 0.1 & 10.6 & \pm 1.3 & 548 & \pm 3 & 569 & \pm 66 & 189.1 & \pm 1.4 & 68.1 & $\pm 5.3^{*}$ \\
\hline $\mathrm{CC} 2$ & 131.9 & \pm 1.8 & 121.7 & \pm 6.5 & 148.3 & \pm 2.6 & 100.1 & $\pm 6.1^{*}$ & 373 & \pm 15 & 285 & $\pm 10^{*}$ & 8.7 & \pm 0.1 & 6.6 & \pm 1.8 \\
\hline $\mathrm{CC} 3$ & $<0.2$ & & $<0.2$ & & $<2$ & & $<2$ & & 4584 & \pm 20 & 4495 & \pm 16 & 59.2 & \pm 0.1 & 42.8 & $\pm 1.9^{*}$ \\
\hline $\mathrm{C} 1$ & 128.9 & \pm 2.5 & 125.0 & \pm 5.8 & 594.4 & \pm 14.0 & 440.3 & $\pm 44.2^{*}$ & 1939 & \pm 15 & 2297 & $\pm 128^{*}$ & 652.4 & \pm 16.4 & 520.0 & $\pm 33.6^{*}$ \\
\hline $\mathrm{C} 2$ & 342.4 & \pm 11.6 & 199.7 & $\pm 15.1^{*}$ & 52.7 & \pm 1.5 & 35.3 & $\pm 1.8^{*}$ & 2074 & \pm 76 & 2242 & \pm 158 & 30.6 & \pm 1.1 & 24.3 & $\pm 1.4^{*}$ \\
\hline CW & 0.7 & \pm 0.0 & 4.1 & \pm 5.5 & 30.5 & \pm 7.0 & 7.2 & \pm 7.4 & 3880 & \pm 39 & 4313 & $\pm 39 *$ & 49.7 & \pm 1.5 & 46.3 & \pm 2.5 \\
\hline
\end{tabular}


Weathering resulted in a slight decrease in Ca content in substrates with a low initial Ca content and increase in substrates with a high initial Ca content (Table 3); the increase in $\mathrm{Ca}$ content caused by weathering was positively correlated with the Ca content before weathering $(r=0.804, p<0.05)$. Weathering caused a decrease in conductivity of substrates with a high initial conductivity and low $\mathrm{pH}$ and increase at sites with a high initial $\mathrm{pH}$ (Fig. 1C); conductivity change was negatively correlated with initial conductivity and negatively with initial $\mathrm{pH}(r=-0.777$ and 0.770 , respectively; $p<0.05$ in both cases).

A PCA ordination diagram summarized the relationships between chemical properties of individual overburden materials during weathering. Coal-rich and coalfree clays are clearly separated along the first ordination axis, which explained most of the variability in the data (Fig. 2). Coal-rich clays were characterized by a decrease in conductivity and Ca content and increase in $\mathrm{pH}$ during weathering. Coal-free clays were characterized by an increase in conductivity and Ca content and decrease in $\mathrm{pH}$ during weathering.

Weathering resulted in seedlings of $S$. alba growing significantly poorer in all coal-free substrates $(\mathrm{C} 1, \mathrm{C} 2$, and $\mathrm{CW}$ ), better in one coal-rich substrate (CC2) and had no significant effect on their growth in the other substrates (Fig. 1D). S. alba seedlings did not grow in two of the coal-rich clays, whether weathered or not (Fig. 1D), despite an increase in $\mathrm{pH}$ with weathering (Fig. 1A). The inability of $S$. alba seedlings to grow in these weathered substrates may be due to their high As content (Fig. 1B); however, there were no significant correlations between growth of seedlings and the As contents of either the un- weathered or weathered substrates. Plant growth after weathering was positively correlated with available $\mathrm{Al}$, $\mathrm{Na}$, conductivity and $\mathrm{pH}(r=0.762,0.767,0.748$ and 0.763 for available $\mathrm{Al}, \mathrm{Na}$, conductivity and $\mathrm{pH}$, respectively; $p<0.05$ in all cases).

\section{Discussion}

In agreement with previous studies (Frouz et al. 2004; Frouz et al. 2011b), the current study indicates that substrate $\mathrm{pH}$ is a good predictor of overburden toxicity and suitability as a substrate for growing plants. Based on our results, this is true for unweathered and weathered, overburden even though $\mathrm{pH}$ and plant performance changed significantly with weathering. The effect of weathering on the $\mathrm{pH}$ of acidic coal-rich and alkaline coal-free clays differed. For acidic coal-rich clays $\mathrm{pH}$ increased with weathering for all but one these clays and the suitability for plant growth remained the same or increased. The $\mathrm{pH}$ increase was more pronounced for clays that were initially very acidic. For alkaline coal-free clays, in contrast, $\mathrm{pH}$ decreased and plant growth deteriorated with weathering. The reason for this is not clear; but we suspect that the decrease in plant performance after weathering is an increase in conductivity, which is known to be associated with toxicity in alkaline spoils (Frouz et al. 2004). That the changes in chemistry during weathering differ in coal-rich and coal-free Miocene clays is reported in a previous study (Haering et al. 1993).

Another factor that may reduce plant growth in some substrates is a high As content. Arsenic content alone, however, does not seem to be critical because the As con-
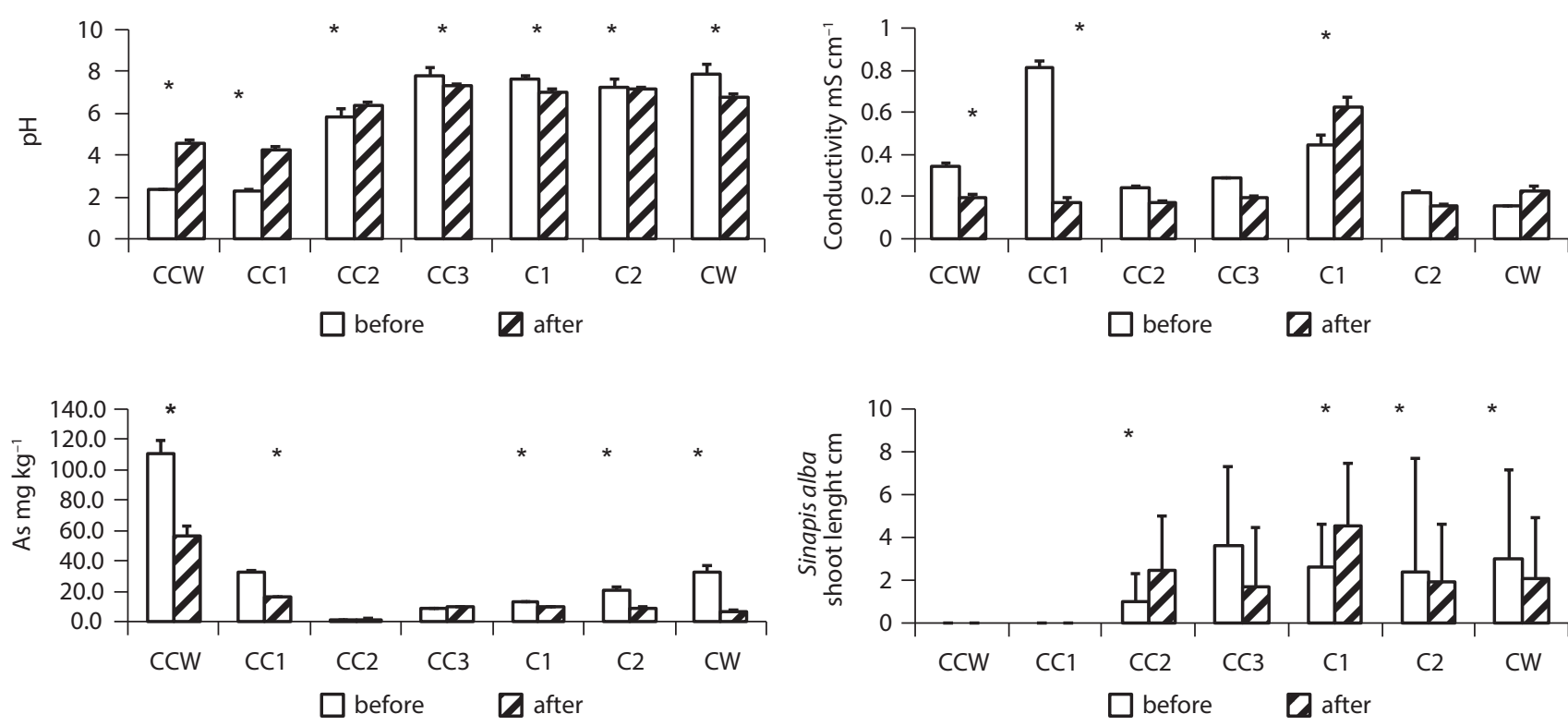

Fig. 1 Effects of artificial weathering of substrates from the coal-mine on their $\mathrm{pH}(\mathrm{A})$, As content (B), electrical conductivity (C) and lengths of the shoots of plants (Sinapis alba) growing in these substrates (D). One half of each substrate sample was artificially weathered and one was not. Values are means \pm SD. An asterisk indicates a significant difference between values obtained before and after weathering. 


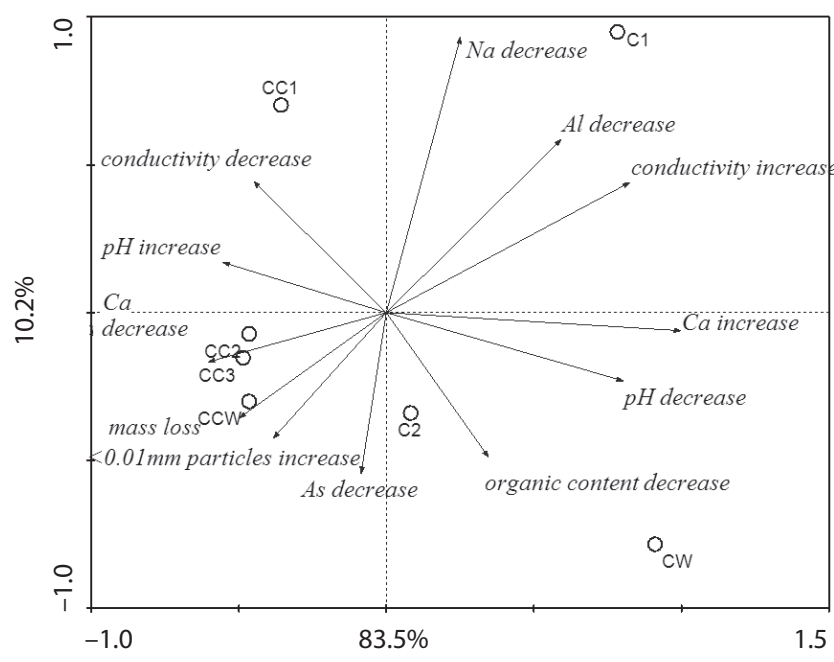

Fig. 2 Changes in the properties of coal-mine substrates resulting from weathering indicated by principal component analysis (PCA).

tents of some coal-free overburdens were as high as those of coal-rich overburdens but were not toxic to plants. It is more likely that it is the interaction between As, $\mathrm{pH}$ and other properties of substrate that are critical. This corresponds with the fact that the toxicity of As and metals strongly depends on $\mathrm{pH}$, sorption and other properties of substrates (Posthuma et al. 1988; van Gestel 1992; van Gestel and Hoogerwerf 2001), and it is this that accounts for the lack of a correlation between plant growth and As content in this study.

Weathering also reduces the contents of As and available $\mathrm{Na}$ and $\mathrm{Al}$, probably via leaching. The opposite is true for available $\mathrm{Ca}$, which increased during weathering. This may partly affect $\mathrm{pH}$ because before weathering, available $\mathrm{Ca}$ is negatively correlated with $\mathrm{pH}$ and the loss is higher in acidic conditions (Silva et al. 2011).

In general, coal-free clays support better plant growth than coal-rich clays, both before and after weathering, even though a slight decrease in plant growth can occur when coal-free clays are weathered. Although weathering improves conditions of acidic coal-rich clays for plant growth it may still be poor if the $\mathrm{pH}$ of these substrates is below 5 and if the As contents are increased. Such acidic coal-rich overburden may not support reasonable plant growth even after decades of weathering.

Differences in the composition of organic matter may also contribute to differences in the phytotoxicity of coalrich and coal-free substrates. Coal is the major organic component of coal-rich clays and may release potentially toxic phenols during decomposition. a previous study reports a positive correlation between coal and phenol contents and post-mining substrate toxicity (Frouz et al. 2004). Kerogen, in contrast, is the major organic component of coal-free clays and is likely to produce mostly harmless aliphatic compounds during decomposition (Kříbek 1997).

The organic matter in all the substrates decreased substantially during weathering (Table 2). This loss may have resulted from the removal of small fragments of organic matter when water was decanted from the bottles and from mineralization. Although both mechanisms may have occurred in all substrates, the former is probably important in coal-rich substrates because such substrates contain coal dust. The latter mechanism is probably more important in coal-free clays, because kerogen is bound to the mineral matrix (Kř́bek et al. 1998; Rojík 2004). However, the microbial degradation of both coal and claybound organic matter is reported (Machnikowska et al. 2002; Frouz et al. 2011a). Our results suggest that fossil organic matter is not very stable and its loss may be important in the overall carbon budget of developing post mining soils. a previous study (Šourková et al. 2005) that compared the organic matter content of substrates along a chronosequence of post mining sites reports a decrease in organic matter content in the early stages of development of post mining soils. This was explained in terms of the heterogeneity in materials between sites (Šourková et al. 2005); our results, however, show that weathering can result in a loss of fossil organic matter.

The loss of mass from the different substrates was very variable. Because no particles were visible in the decanted water, we infer that much of the mass that was lost was in the form of soluble compounds or very fine particles in the case of coal-rich clays. The mechanisms of mass loss may therefore include the leaching of dissolved solids, the removal of clay and colloidal coal by moving water and the mineralization of organic matter. The different mechanisms resulting in loss of mass may also account for why it is not associated with any of the other variables measured. The close association between mass loss and water-holding capacity after weathering indicates that penetration of a substrate by water is essential for weathering. An increase in water-holding capacity as a result of weathering may also substantially improve conditions for plant growth at post-mining sites.

\section{Acknowledgements}

This study was supported by grant GA206/09/1642 from the Czech Science Foundation. We greatly appreciated the technical support provided by the Sokolovská uhelná, právní nástupce a.s. mining company.

\section{REFERENCES}

Bradshaw A (1997) Restoration of mined lands - using natural processes. Ecol Eng 8: 255-269.

Doolittle JJ, Hossner LR (1997) Acid-base properties of a limed pyritic overburden during simulated weathering. J Environ Qual 26: $1655-1662$.

Frouz J, Cajthaml T, Kř́bek B, Schaeffer P, Bartuška M, Galertová, R, Rojík, P, Krištůfek V (2011a) Deep, subsurface microflora after excavation respiration and biomass and its potential role in degradation of fossil organic matter. Folia Microbiol 56: 389-396. 
Frouz J, Hrčková K, Lána J, Krištůfek V, Mudrák O, Lukešová A, Mihaljevič M (2011b) Can laboratory toxicity tests explain the pattern of field communities of algae, plants, and invertebrates along a toxicity gradient of post-mining sites? Appl Soil Ecol 51: 114-121.

Frouz J, Krištůfek V, Bastl, J, Kalčík J, Vaňková H (2004) Determination of toxicity of soil substrates after brown coal mining using a laboratory reproduction test with Enchytraeus crypticus (Oligochaeta). Water Air Soil Poll 162: 37-47.

Haering KC, Daniels WL, Roberts JA (1993) Changes from overburden properties resulting from overburden weathering. J Environ Qual 22: 194-200.

Helingerová M, Frouz J, Šantrůčková H (2010) Microbial activity in reclaimed and unreclaimed post-mining sites near Sokolov (Czech Republic). Ecol Eng 36: 768-776.

Klute A (1986) Methods of Soil Analysis, Part 1 Am. Soc. Agron., Madison, Wisconsin.

Krríbek B (1997) Weathering of organic material from the Miocene Brown shale (Sokolov basin: Czech Republic): environmental and remediation aspects. Mineral Deposits 67-70.

Kř́ibek B, Strnad M, Boháček Z, Sýkorová I, Čejka J, Sobalík Z (1998) Geochemistry of Miocene lacustrine sediments from the Sokolov Coal Basin (Czech Republic). Int J Coal Geol 37: 207-233.

Machnikowska H, Pawelec K, Podgórska A (2002) Microbial degradation of low rank coals. Fuel Process Technol 77-78: 17-23.

Mehlich A (1953) Determination of P, Ca, Mg, K, Na, and NH4, North Carolina Soil Test Division, Mimeo.
Posthuma L, Noteboom J, de Groot AC, Peijnenburg WJGM (1988) Soil acidity as a major determinant of zinc partitioning and zinc uptake in oligochaete worms exposed in contaminated field soils. In: Sheppard S, Bembridge JJD, Holmstrup M, Posthuma L (eds) Advances in Earthworm Ecotoxicology. SETAC Publishers, Pensacola, FL, USA, pp. 111-127.

Rojík P (2004) New stratigraphic subdivision of the Tertiary in Sokolov Basin in Northwestern Bohemia. J Czech Geol Soc 49: 173-186.

Silva LFO, Querol X, da Boit KM, de Vallejuelo SF, Madariaga JM (2011) Brazilian coal mining residues and sulphide oxidation by Fenton's reaction: An accelerated weathering procedure to evaluate possible environmental impact. J Hazard Mater 186: 516-525.

Šourková M, Frouz J, Šantrůčková H (2005) Accumulation of carbon, nitrogen and phosphorus during soil formation on alder spoil heaps after brown-coal mining, near Sokolov (Czech Republic). Geoderma 124: 203-214.

van Gestel CAM (1992) The influence of soil characteristics on the toxicity of chemicals for earthworms: a review. In: Greig-Smith PW, Becker H, Edwards PJ, Heimbach F (eds) Ecotoxicology of Earthworms. Intercept Press, Andover, UK, pp. 44-54.

van Gestel CAM, Hoogerwerf G (2001) Influence of soil pH on the toxicity of aluminium for Eisenia andrei (Oligochaeta: Lumbricidae) in an artificial soil substrate. Pedobiologia 45: 385-395.

Zipper CE, Burger JA, McGrath JM, Rodrigue JA, Holtzman GI (2011) Forest Restoration Potentials of Coal-Mined Lands in the Eastern United States. J Environ Qual 40: 1567-1577. 